\title{
EFFECT OF A BACTERIAL CONSORTIUM ON OXIDATIVE STRESS IN SOYBEAN PLANTS IN CADMIUM-CONTAMINATED SOIL
}

\author{
Zaets I. E. ${ }^{1,2}$, Kozyrovska N. O. ${ }^{2}$ \\ ${ }^{1}$ Taras Shevchenko Kyiv National University, Volodymyrska str., 64, 01033 Kyiv, Ukraine; \\ ${ }^{2}$ Institute of Molecular Biology\&Genetics of NASU, Acad. Zabolotnoho str., 150, 03680 Kyiv, Ukraine \\ ladomir1981@list.ru
}

\begin{abstract}
There are different mechanisms of heavy metal resistance in soybean at different concentrations of cadmium in a soil. For instance, at 10 maximum permissible concentration (MPC) of cadmium in the soybean roots oxidative burst is more prolonged, and glutathione-S-transferase carries out a basic contribution to overcoming stress. At the same time, doth guaiacol peroxidase and phenols play main role in a reducing toxicity of cadmium at $100 \mathrm{MPC}$, and glutathione-S-transferase does in a lesser degree. The consortium of bacteria inhibit activity of peroxidase and so far elevate $\mathrm{H}_{2} \mathrm{O}_{2}$ concentration during oxidative burst which in turn results in strengthening expression of the genes encoding glutathione-S-transferase and enzymes of phenilpropanoid metabolism, and, finally, in more effective overcoming stress by plants.
\end{abstract}

Key words: bacterial consortium, Glycine max. L., heavy metals, oxidative stress, glutathione-S-transferase, guaiacol peroxidase, soluble phenols.

Introduction. Heavy metals (HM) - metals with a density above $5 \mathrm{~g} / \mathrm{cm}^{3}$ - are one of the most toxic pollutants of the environment. They occur in a soil as waste products of industrial enterprises, traffic, space-heating systems, and fertilizers. In particular, cadmium which is of the first class of hygienical danger [HOST (State Standard) № 17.4.1.01-83], easily enters the plants and moves over xylem to the vegetative and generative organs, and this results in a reduction of agricultural plants productivity and human intoxication [1-3 ].

As a result of the HM direct action on a living organism under assistance of the membrane NADPH-oxidase induced by both biotic and abiotic stresses, the reactive oxygen species (ROS) generate so-called "oxidative burst". ROS are high-reactive and

(C) I. E. ZAETS, N. O.KOZYROVSKA, 2008 toxic and can cause oxidative stress in plants that is accompanied the processes of a free-radical oxidation (FRO) of lipids, proteins, acid polysaccharides and nucleic acids in the plant cell $[2,4,5]$. On the other side, ROS (mainly $\mathrm{H}_{2} \mathrm{O}_{2}$ and $\mathrm{O}^{-2}$ ) take part in early defense events against abiotic and biotic stresses $[6,7]$.

There are antioxidant defense systems for adjusting the ROS level in cells. There are enzymes which inactivate ROS [superoxide dismutase (SOD), catalase, peroxidases etc.], products of peroxide oxidation of lipids associated with development of FRO (glutathione peroxidase), toxic products of FRO, and the damaged cell components (glutathione-S-transferase) [2]. Either an increase or a decline of the antioxidant enzymes activity in dependence on the plant organ and metal concentration were indicated in different studies [2,4, 8-10]. It is 
assumed that under moderate stress conditions, a plant responds on stressors by increasing the antioxidant enzymes activity, however, under extreme toxicity a general failure of the metabolism causes its attenuation $[2,4]$. Activation of SOD and inhibition of the glutathione reductase, catalase and ascorbate peroxidase activities (as a result of blocking their SH-groups) results in $\mathrm{H}_{2} \mathrm{O}_{2}$ accumulation and causes the oxidative burst, however, finally, it activates catalase, ascorbate peroxidase and glutathione-S-transferase activities to overcome the stress [2].

The long-term studies allowed to define the plant genes which are regulated by cadmium, and also to establish the mechanism of plant tolerance to this metal $[11,12]$. In particular, it is shown that phytochelatins bind metal cations and compartmentalized them in vacuoles. The objective of our study was to define whether the bacteria of a rationally assembled consortium promoted restoration of an oxidant-antioxidant homeostasis in the soybean grown on the artificially polluted by cadmium plots. The prerequisites for this were the facts that a long-term exposition of plants to high HM concentrations resulted in development of the acquired systemic resistance [5], on one side, and that bacteria can induce systemic resistance in plants to stress agents, on the other side $[6,7]$.

\section{Materials and Methods}

The followings species of bacteria were included in the consortium used for a presowing plant treatment: Pseudomonas sp. IMBG163, Pseudomonas aureofaciens IMBG164, Paenibacillus sp. IMBG156, Klebsiella oxytoca IMBG26, Pantoea agglomerans IMV56, and Stenotrophomonas maltophilia IMBG147. Bacteria were grown in following nutrient media: Paenibacillus sp.- in MZ [13], pseudomonads - in KB [14], the other cultures - in LB broth [15] during 18-24 hours.

The study was conducted in 2006 year at Erastivska Research Station of Institute of the Grain Farming of UAAS in a grain-fallow crop rotation. Soybean plants (Glycine max L.) of Podil'ska 416 cultivar were grown in the soil with added cadmium when needed, exceeding maximum permissible concentration (MPC) in 10 and 100 times (10 and $100 \mathrm{MPC}$ ) of a gross output (it was added in the form of $0.1 \mathrm{~N}$ water solution of $\mathrm{CdSO}_{4}$ ). Inoculation of soybeans with the bacterial consortium was executed immediately prior sowing. Before the use, a suspension of bacterial strains mixed in equal proportions at titre of $10^{9} \mathrm{CFU} / \mathrm{ml}$ was diluted in 100 times to a final titre.

A plant sampling was performed in several periods of time: under forming pseudo leaves, first and second true leaves, during a flowering, and a bean inception (stages 1-5). A protein carbonyl content in plant biomass was determined as described by Semchishin [16], soluble phenols content as described in [17], activity of guaiacol peroxidase (GP, EC 1.11.1.7) as described by Kholodova [18], and glutathione-S-transferase (GT, EC 2.5.1.18) as described by Vlasova [19]. A cadmium content in the soil was determined by flame atomic adsorption spectrophotometry using a C115-M1 (Selmi, Ukraine) [20].

\section{Results and Discussion}

Influence of the bacterial consortium on morpho-physiological parameters of plants at cadmium soil pollution. At the end of soybean plant vegetation a content of mobile forms of $\mathrm{Cd}$ in the soil was 7-17 and 18-27-time less than in plots with the added doses of $\mathrm{Cd}$ (10 and $100 \mathrm{MPC}$ of cadmium correspond 30 and $300 \mathrm{mg} / \mathrm{kg}$ soil, respectively) (Table). A gradual conversion of the added cadmium to the unavailable for plants form was notable. A difference between the bacteria-treated variant and control grown in de bene esse clean soil was more pronounced at $10 \mathrm{MPC}$ : it was a 17-27-fold decrease of Cd mobile forms content, as compared to control. At the same time, at 100 MPC the difference was a 15-23-fold. A high availability of $\mathrm{Cd}$ in the soil resulted in increasing its accumulation in the organs of soybean plants: in leaves - in 4.0 and 37.0 times, in roots - in 3.8 and 39.0, in beans - in 5.6 and 29.0 times at 10 and 100 MPC, respectively. Inoculation the plants with bacteria reduced content of Cd only at 10 MPC in beans (on 33.0 $\%$ ) and roots (on $11.0 \%$ ), while in leaves it rised to 42.5 $\%$. At $100 \mathrm{MPC}$ bacteria promoted $\mathrm{Cd}$ accumulation: in leaves on $39.0 \%$, in roots on $67.0 \%$, in beans on $20.0 \%$.

At 10 and $100 \mathrm{MPC}$ of $\mathrm{Cd}$ in the soil the morphological parameters of plants did not differ from control ones. However, increase of the soil contamination resulted in a plant biomass reducing, 
Influence of the bacterial consortium on cadmium content in the soil and plant biomass, $\mathrm{mg} / \mathrm{kg}$

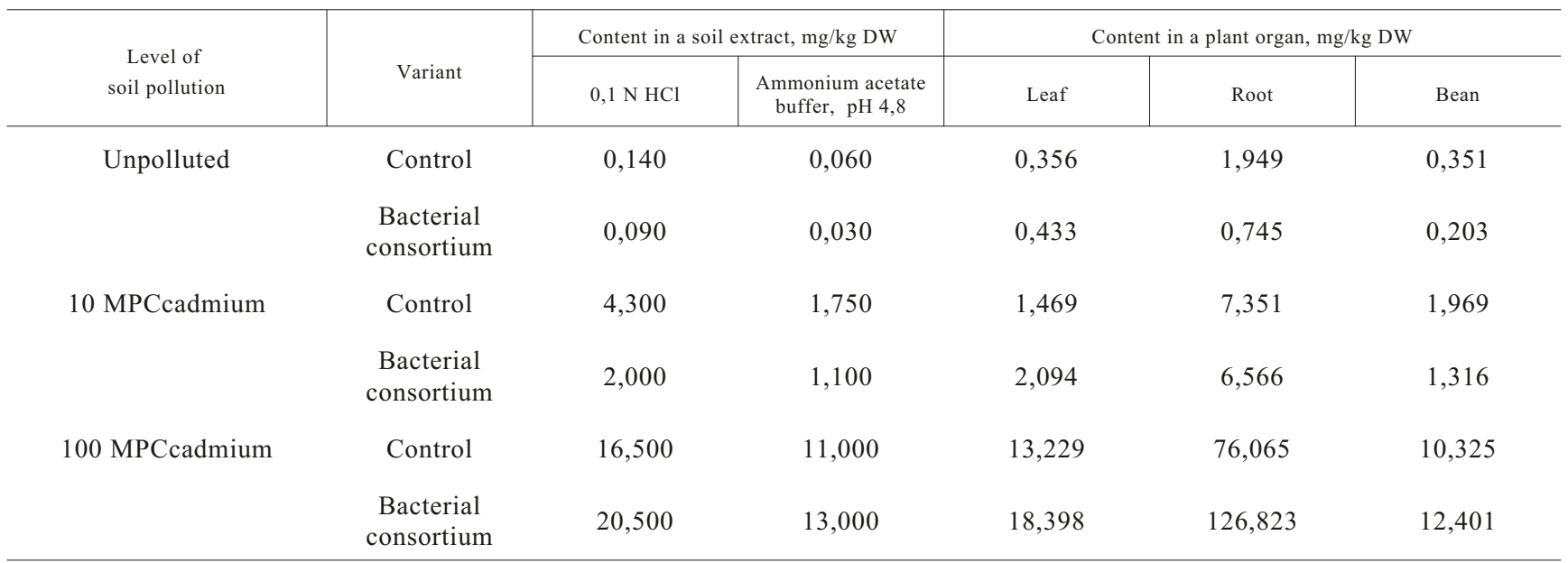

compared to both inoculated and uninoculated plants grown in the provisionally clear soil. This associated also with a plant development falling behind control plants on 5-7 days, and in occurring leaf chlorosis at the 3rd stage which manifested considerable destructive processes. Presowing treatment of soybeans with model bacteria improved efficiency of its germination up to $80 \%$ in all variants of the $\mathrm{Cd}$ contamination, promoted development of the root system and increased plant biomass both in the relatively clean and contaminated soil (data not shown).

Consequently, the bacterial consortium diminished negative influence of cadmium on a plant organism. Inoculation with bacteria on the background of different levels of contamination exhibited an opposite effect on cadmium accumulation in the soybean plant organs. So, at $10 \mathrm{MPC}$ bacteria prevented the plant from $\mathrm{Cd}$ accumulation (except leaves); at the same time, at 100 MPC inoculation resulted in increasing $\mathrm{Cd}$ content in plant biomass. This may have relevance to the effect when at lower concentrations of cadmium in the soil, bacteria decline its bioavailability, however, at high cadmium concentration bacteria exhibit a mobilizing action. A preventive action of bacteria was observed in our previous study on the soil HM contamination ( $\mathrm{Fe}, \mathrm{Mn}, \mathrm{Cu}, \mathrm{Zn}, \mathrm{Cd}$ ) at concentrations of 1-5 MPC [21]. Except a decline of bioavailability of indicated elements, bacteria also reduced HM accumulation in leaves due to a deposition in roots (except $\mathrm{Zn}$ ). This let us to expect that the above-ground vegetative part will be safe for the use, although at a high level of contamination it would be better to apply the bacterial consortium exceptionally for phytostabilization of $\mathrm{HM}$ in combination with phytoextraction.

Influence of the consortium of bacteria on protein oxidation in leaves and roots of soybean plants under soil cadmium contamination. There is a balance between oxygen activating and deactivating within the normal physiologically active plant cell, therefore the amount of ROS remains at a safe level. Under normal conditions, interaction between the bacterial consortium and soybean plants generates an insignificant increase of protein peroxide oxidation which balances at the level of 10-18\% over control during plant growth, and only at a stage of a bean ripening it rises up to $43 \%$. It testifies to the development of a weak oxidative burst and, probably, induction of a system resistance to $\mathrm{Cd}$ and other stressful agents (Fig. 1A).

On the background of both 10 and 100 MPC, protein oxidation is increased in the soybean roots, comparing to control, and this correlated with the added dose of metal only in the first week after the seed germination (34 and $58 \%$, accordingly). After appearance of true leaves the symptoms of the oxidative stress became more expressed under less concentration of cadmium in the soil; at that time, at 100 MPC a difference with control diminished. Consequently, at higher cadmium concentration the alarm stage was completed at the first stage of plant development. At more low $\mathrm{Cd}$ content a plant responded slower, and 

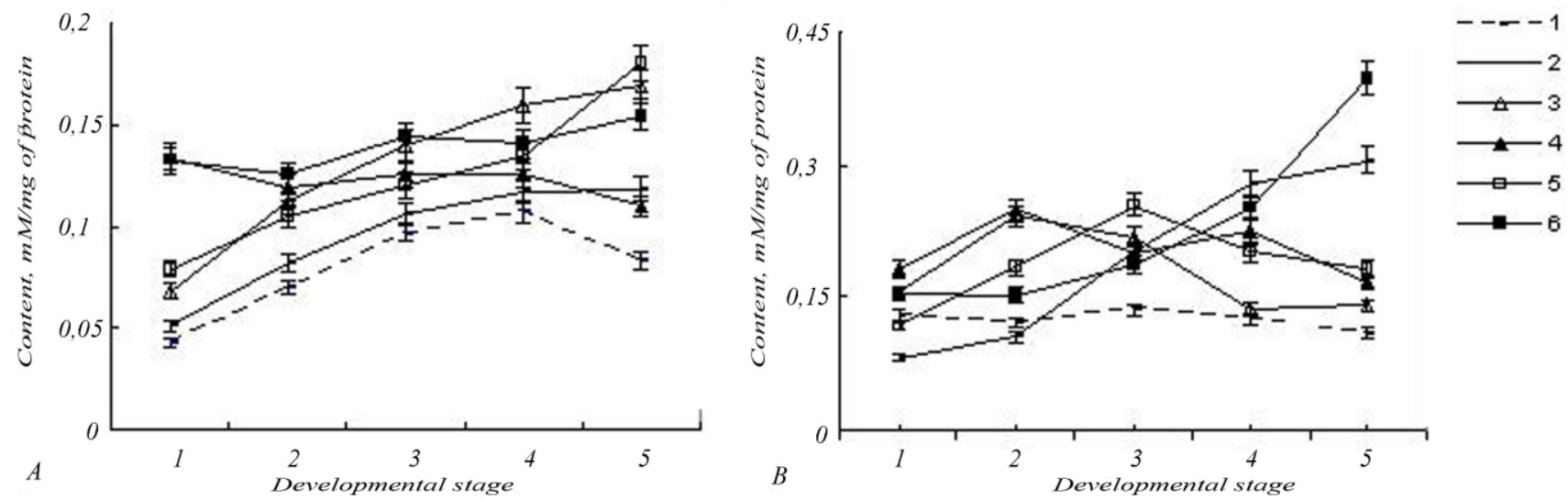

Fig.1. Influence of the bacterial consortium on protein carbonyl content in soybean roots (A) and leaves (B) at cadmium contamination: control on the provisionally clean soil (1), at 10 (3), and $100 \mathrm{MPC}$ (5); the bacterial consortium on the provisionally clean soil (2), at 10 (4) and $100 \mathrm{MPC}(6)$. Developmental stage: 1 - unreal leaves, 2, 3 - the 1 st and 2 nd true leaves, 4 - a flowering, 5 - a bean inception.

maximal oxidative burst was observed only at the second stage. A treatment of soybean with bacteria accelerated adaptation of plants to the stress. At the first stage mechanisms of the $\mathrm{H}_{2} \mathrm{O}_{2}$ formation were initiated, and the increase of cell protein oxidation in 1.6 times was an indirect indication (Fig. 1A). This parameter varied in a very narrow range in the process of plant growth, and that was an evidence of the oxidant-antioxidant reactions stability in the soybean roots.

The content of aldehyde and ketone protein derivatives, occurring in the young soybean leaves, practically did not vary with the time, while a treatment with bacteria increased the content, beginning from the 3rd stage, and at the end of vegetation it resulted in a 3-fold difference (Fig. 1B).

As known, the above-ground part of plants accumulates cadmium [11]. Obviously, mechanisms, limiting $\mathrm{Cd}$ perception by plant, do work not enough effectively at low metal concentration, and a toxic action shows up immediately. Within the first three stages a content of oxidized protein rised and reached a maximum at $10 \mathrm{MPC}$ of cadmium after appearance of the fisrst true leaf, and at $100 \mathrm{MPC}$ after the second one. After that protein oxidation declined, in particular, at low concentration of metal in the soil. In the bacteria-treated plant variants diminishing protein carbonyl content was not observed; on the contrary, at $100 \mathrm{MPC}$ it increased exponentially, and during a bean inception exceeded control in 4 times; that testifies to greater duration of the oxidative burst.
Influence of the bacterial consortium on activity of free guaiacol peroxidases and glutathione-S-transferase in the soybean leaves and roots. The oxidation level of proteins in cells is determined by efficiency of two antioxidant systems. On one side, the processes of ROS neutralization occur, preventing of the cellular macromolecules FRO (one of the most active components of this system is nonspecific peroxidase that oxidizes phenolic substrates), and, on the other side, there is detoxication of FRO products under GT assistance.

Plants have a basic level of the antioxidant enzymes activity that is rising in a course of time through progress of protein oxidation within the process of senescence. Growth of the plant roots is accompanied the enzyme activities promotion, mainly GT. Inoculation plants with bacteria resulted in diminishing the GP activity in the roots in 2.3-3.0 times at 1-3 stages, and declining the GT activity in 1.6-2.6 times at 3-4 stages (Fig. 2A, 2C). Only during a flowering the GP activity rised; at the same time, the GT activity was being not changed practically, however, during a bean ripening it grew up to the control level.

A growth of soybean plants in the soil with high cadmium content accompanied the sharp increasing the GP activity in 2 times after appearance of the 1st true leaf and during a flowering it decreased to initial level, again beginning to rise at a bean ripening. It may be predefined by induction of system resistance at the initial stage of plant growth, when inhibition of the 

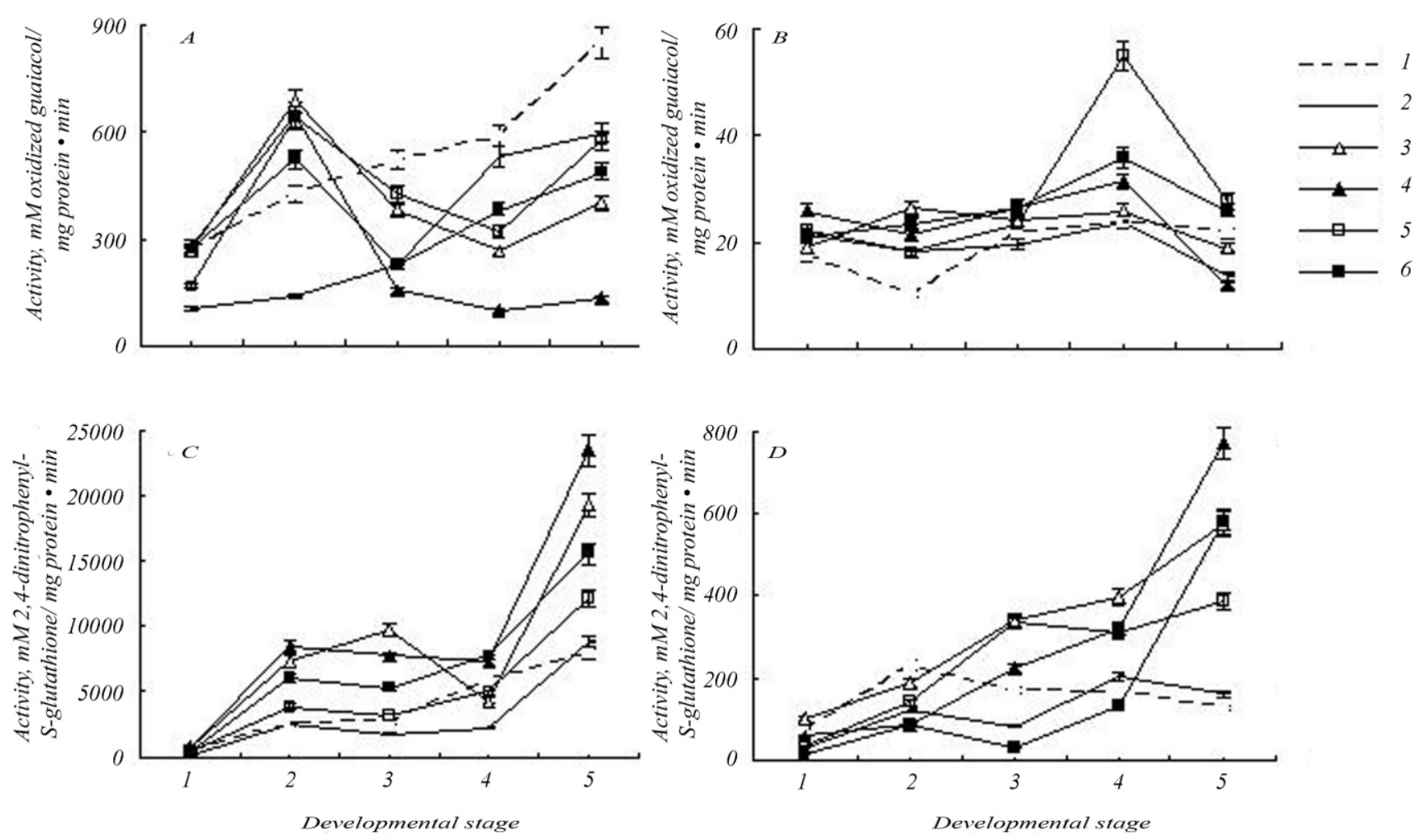

Fig.2. Influence of the bacterial consortium on activity of free guaiacol peroxidase (A, B) and glutathione-S-transferase (C, D) of the soybean roots $(\mathrm{A}, \mathrm{C})$ and leaves $(\mathrm{B}, \mathrm{D})$ at cadmium contamination: control in the provisionally clean soil (1), at 10 (3) and $100 \mathrm{MPC}$ of cadmium (5); the bacterial consortium in the provisionally clean soil (2), at 10 (4) and $100 \mathrm{MPC}(6)$.

ascorbate peroxidase and catalase activities occured to enhance a signal transduction during the oxidative burst [6]. A treatment of plants with bacteria accelerated acquisition of resistance to the cadmium which certified the 6.5-time GP activity inhibition already before the $3 \mathrm{rd}$ stage of the plant development at $10 \mathrm{MPC}$ of cadmium, compared to control. However, at $100 \mathrm{MPC}$ this enzyme activity again rised up to $75 \%$ of control. Thus, at the extremely high concentrations of cadmium the alarm stage was ended earlier, and a plant recovered the metabolism more fast.

GT is one of key plant enzymes in a system resistance induced by stress (an attack of pathogens, an osmotic shock etc.) [22]. It is activated, as well as GP, after formation of the 1 st true leaf. At $10 \mathrm{MPC}$ a rise of the activity proceeded to the next stage, and after that there was a sharp slop to the control level, while at 100 MPC a fall was completed at the 3 rd stage. Soon after there was the reactivation of enzyme in both variants which was analogical to the increase of the GT activity in the inoculated plants grown in the unpolluted soil.
Bacteria promoted the GT activity, not changing the character of the curve here. It is possible to make conclusion that resistance to cadmium at the concentration of $10 \mathrm{MPC}$ is formed after the flowering stage, and at 100 MPC this happens at a stage earlier.

In leaves there was the same interdependency between enzyme activities (Fig. 2B, 2Г). The GP activity was low at the first two stages of control plant, however, in the sequel it rised in 1.1-2.5 times. The GP activity in inoculated plants rised in 1.3-2.0 times at the early stages and remains at the same level till a flowering, diminishing in 1.7 times at the end of plant vegetation. The same increase of activity occured at the Cd-induced stress, however, at 100 MPC of cadmium at the flowering stage there was a peak which exceeded control in 1.5 times. A treatment with bacteria promoted increase of the enzyme activity, but peak at the flowering stage appeared at both concentrations of cadmium in the soil, although less expressed.

On the contrary, the GT activity grew in $26-28$ times linearly in uninoculated soybean plants, and rised 

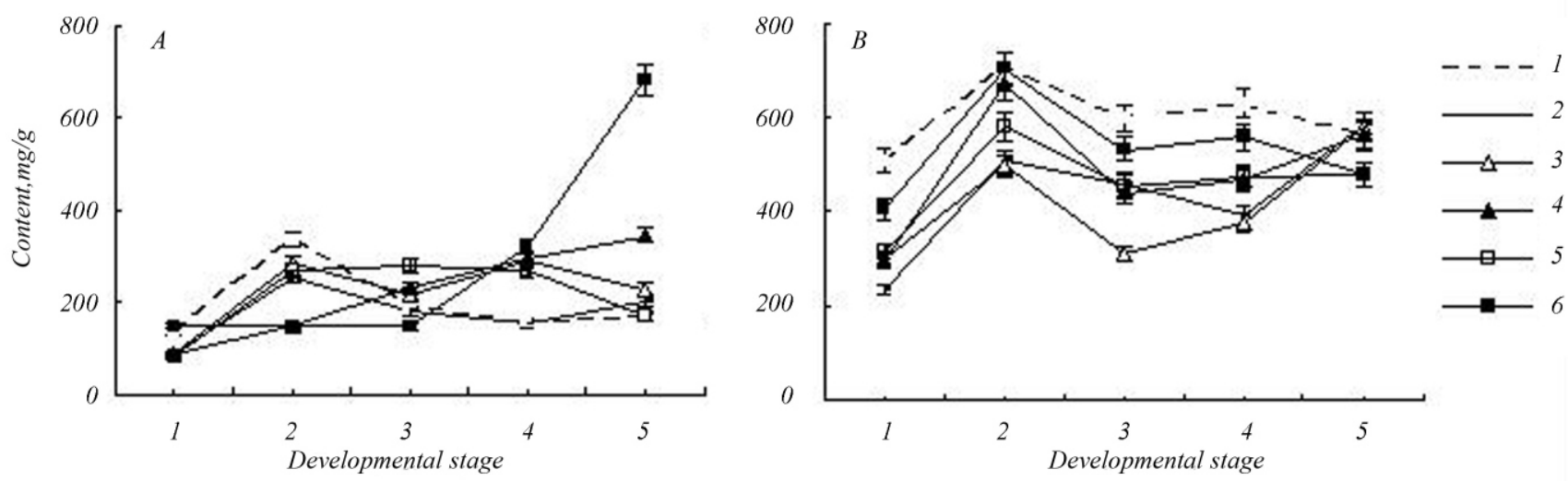

Рис.3. Influence of the bacterial consortium on a soluble phenol content in the soybean roots (A) and leaves (B) at cadmium contamination: control in the provisionally clean soil (1), at 10 (3) and $100 \mathrm{MPC}$ of cadmium (5); the bacterial consortium in the provisionally clean soil (2), at 10 (4) and $100 \mathrm{MPC}(6)$.

exponentially in 30-40 times in the inoculated plants grown on the cadmium-contaminated areas. At a higher dose of Cd the enzyme activity was on 51-58 \% lower. In particular, in the case of $100 \mathrm{MPC}$ it was below a level of the inoculated plants grown on the soil without addition of $\mathrm{Cd}$. However, a decline of the GP activity at the end of plant vegetation resulted in compensating sharp increase of the GT activity.

Analyzing data resulted from Figure 2, we may conclude that at the initial stages of plant growth under high concentrations of cadmium in the substrate a level of protein peroxide oxidation depends on the concerted work of the antioxidant enzymes, such as free guaiacol peroxidases and glutathione-S-transferases. At that, the more actively GP neutralizes $\mathrm{H}_{2} \mathrm{O}_{2}$, the less work for detoxication of the modified proteins (and also other biomacromolecules) remains for GT. And vice versa, a decline of the GP activity is compensated by increase of the GT activity. Due to inhibition of the peroxidase activity bacteria enhance a signal during the oxidative burst which triggers plant defense mechanisms. In turn, it enhances expression of the genes encoding GT needed to restore oxidized proteins to the basic level.

Influence of the bacterial consortium on content of soluble phenolic compounds (PC) in the soybean leaves and roots. Biosynthesis and oxidation of $\mathrm{PC}$ is one of the first respond of the plant on a stress. In the soybean roots of both uninoculated and inoculated plants PC content rised at appearance of the true leaves, and this coincided with plant growth promotion and a root branching (Fig. 3A). These substances served for adjusting availability of chemical elements, and played an important role in the relationships of plants with rhizosphere microorganisms [4]. Therefore, the enhanced biosynthesis of phenols in the roots could take place with a purpose of subsequent excretion and defense against pathogens.

There was a different scenario under plant growing in the cadmium-polluted soil. Although PC content in the roots of uninoculated plants was below control level till the second growth stage, the subsequent fall of their biosynthesis took place only at the 5th stage which could testify to phenol participating in detoxication/binding of cadmium ions in the roots. A treatment of soybean plants grown at high concentrations of cadmium in the soil with bacteria declined the accumulation of phenols at the first stages of plant growth, and that is in proportion to concentration of cadmium. However, beginning from the 3rd stage at $10 \mathrm{MPC}$ and 4th stage at $100 \mathrm{MPC}, \mathrm{PC}$ biosynthesis was being increased, that, probably, testified to completion of the alarm stage and transition to the stage of resistance to the stressor action. An activating peroxidase had to be due to this situation (a positive feed-back substrate regulation). Increase of PC content in the plant roots was more obvious at high concentration of cadmium in the soil. Very likely, here an intracellular cadmium level 
reached a necessary threshold for a switching on detoxication mechanisms at more early stages.

At the same time, leaves are the main location of phenols biosynthesis. A content of PC rised already in the first true leaves, and then their biosynthesis diminished insignificantly (Fig. 3B). A treatment with bacteria diminished also a content of these compounds in 1.5-2.0 times. Only at the end of vegetation a plant began to accumulate PC in leaves, probably, for an outflow to beans and use them as germination inhibitors. Cadmium addition drew the same effect on PC content in the soybean leaves as a plant inoculation with bacteria. At high concentrations of cadmium in the soil bacterial inoculation promoted the increase of PC accumulation that stronger expressed at $100 \mathrm{MPC}$, and it was related to the increase of cadmium accumulation in leaves [21].

Thus, the bacterial consortium diminishes negative impact of cadmium on a plant growth. Model bacteria promote acquisition of resistance to $\mathrm{Cd}$ in soybean plants due to enhancement of the oxidative burst which stimulates in turn both a biosynthesis and activity of plant antioxidant system components. Similar mechanisms were observed when this consortium was used for growing French marigold in anorthosite rock under excess of $\mathrm{HM}$ and low bioavailability of plant-essential macro- and microelements [23].

\section{Заєиь I. С., Козировська Н. О.}

Вплив консорціуму бактерій на розвиток окисного стресу у рослин сої при забрудненні грунту кадмієм

Резюме

При різних конщентраціях кадмію у грунті спрацьовують різні механізми стійкості сої до дії важких металів. Так, у коренях сої при перевищенні гранично допустимої концентрачї̈ кадмію (ГДК) у 10 разів окисне збурення є пролонгованішим і основний внесок у подолання стресу робить глутатіон-S-трансфераза, у той час як при 100-разовому перевищенні ГДК зменшення токсичності кадмію здійснюється за рахунок гваяколпероксидази і фенолів та меншою мірою - глутатіон-S-трансферази. Завдяки інгібуванню активності пероксидази бактерії консориіуму сприяють підвищенню концентраиії пероксиду водню під час окисного збурення, що в свою чергу посилює експресію генів глутатіон-S-трансферази i ферментів фенілпропаноїдного метаболізму та ефективніше допомагає рослинам долати стрес.

Ключові слова: консориіум бактерій, Glycine тах. L., важкі метали, окисний стрес, глутатіон-S-трансфераза, гваяколпероксидаза, розчинні феноли.
Заеи И. Е., Козыровская Н. А.

Влияние консорциума бактерий на развитие окислительного стресса у растений сои при загрязнении почвы кадмием

Резюме

При разных концентрациях кадмия в почве срабатывают разные механизмы устойчивости растений к действию тяжелых металлов. Так, в корнях сои при 10-кратном превыщении максимально допустимой концентрации (МДК) кадмия окислительный взрыв более пролонгирован и основной вклад в преодоление стресса вносит глутатион-S-трансфераза, в то время как при 100-кратном превышении МДК токсичность кадмия уменьшается посредством гваяколпероксидазы и фенолов и в меньшей степени - глутатион-S-трансферазы. Благодаря ингибированию активности пероксидазы бактерии консорииума усиливают процесс образования перекиси водорода во время окислительного взрыва, что в свою очередь, приводит к усилению экспрессии генов глутатион-S-трансферазы и ферментов фенилпропаноидного метаболизма $и$ помогает растениям эффективнее преодолевать стресс.

Ключевые слова: консорииум бактерий, Glycine max. L., тяжелые металлы, окислительный стресс, глутатион-S-трансфераза, гваяколпероксидаза, растворимые феноль.

\section{REFERENCES}

1. Shevchenko O.V., Budzanivska I.G., Patika V.P., Boyko A.L., Polischuk V.P.. Effect of heavy metals on the development of plant virus infection. - K.: Phytocenter.- 2003.- 224 p.

2. Schutzendubel A., Schwanz P., Teichmann T., Gross K., Langenfeld-Heyser R., Godbold D. L., Polle A. Cadmiuminduced changes in antioxidative systems, hydrogen peroxide content, and differentiation in Scots pine roots // Plant Physiol.-2001.-127, N 3.-P. 887-898.

3. Alloway B. J., Steinnes E. Anthropogenic additions of cadmium to soils // Cadmium in soils and plants.-Dordrecht: Kluwer Acad. Publ., 1999.- P. 97-123.

4. Schutzendubel A., Polle A. Plant responses to abiotic stresses: heavy metal-induced oxidative stress and protection by mycorrhization // J. Exp. Bot.-2002.-53, N 372.-P. 13511365 .

5. Stohs S. J., Bagchi D., Hassoun E., Bagchi M. Oxidative mechanisms in toxicity of metal ions // Free Radic. Biol. Med.-2001.-18.-P. 321-326.

6. Van Peer R., Niemann G. J., Schippers B. Induced resistance and phytoalexin accumulation in biological control in Fusarium wilt of carnation by Pseudomonas sp. strain WCS417r // Phytopathology.-1991.-81.-P. 728-734.

7. Wei G., Klopper J. W., Tuzun S. Induction of systemic resistance of cucumber to Colleotrichum orbiculare by select strains of plant growth-promoting rhizobacteria // Phytopathology.-1991.-81.-P. 1508-1512.

8. Gajewska E., Skiodowska M. Effect of nickel on ROS content and antioxidative enzyme activities in wheat leaves // BioMetals.-2007.-20, N 1.- P. 27-36.

9. Rodriguez-Serrano M., Romero-Puertas M. C., Zabalza A., Corpas F. J., Gymez M., Del Rio L. A., Sandalio L. M. Cadmium effect on oxidative metabolism of pea (Pisum sativum L.) roots. Imaging of reactive oxygen species and 
nitric oxide accumulation in vivo // Plant, Cell and Environ.-2006.-29, N 8.- P. 1532-1544.

10. Pal M., Horvath E., Janda T., Paldi E, Szalai G. Physiological changes and defense mechanisms induced by cadmium stress in maize // J. Plant Nutr. Soil Sci.2006.-169.-N 2.-P. 239-246.

11. Cobbett $C$. $S$. Phytochelatins and their roles in heavy metal detoxification // Plant Physiol.-2000.-123, N 3.-P. 825-832.

12. Fusco N., Micheletto L., Dal Corso G., Borgato L., Furini A. Identification of cadmium-regulated genes by cDNA-AFLP in the heavy metal accumulator Brassica juncea L. // J. Exp. Bot.-56, N 421.-P. 3017-3027.

13. Negrutska $V$., Kozyrovska $N$. Ecologically-friendly crop production with microbial inoculants. I. The Dual, technology for inoculant production // Int. conf. Natural Ecosystems of the Carpathian Mountains Under Conditions of Intensive Anthropogenic Impact (Uzhhorod, Ukraine).-Uzhhorod, 2001.-P. 76-79.

14. King E., Ward M. K., Raney D. E. Two simple media for the demonstration of pyocyanin and fluorescin // J. Lab. Clin. Med.-1954.-44.-P. 301-307.

15. Miller J. H. Experiments in molecular genetics.-New York: Cold Spring Harbor Lab. publ., 1972.-432 p.

16. Semchishin G., Luschak V., Ogori K.. Probable origin of different oxygen sensitivity of two Escherichia coli strains// Biochemistry.-2005.-70, № 5.-P. 514-522.

17. Madhaiyan M., Poonguzhali S., Senthilkumar M., Seshadri M., Chung S., Yang H. Growth promotion and induction of systemic resistance in rise cultivar Co-47 (Oryza sativa L.) by Methylobacterium spp. // Bot. Bull. Acad. Sin.-2004.-45.P. 315-324.

18. Kholodova V., P., Volkov K.S., Kuznetsov V.V. Adaptation of the common ice plant to high copper and zinc concentrations and their potentisl using for phytoremediation// Russian Journal of Plant Physiology.-2005.- 52, № 6.-C. 848-858.

19. Vlasova S.N., Shabunina E.I. Pereslegina I.A. Activity of erythrocyte glutathione-dependent enzymes at chronic liver diseases in children// Lab. Delo.-1990.-№ 8.-C. 19-21.

20. Panda S. K., Choudhury S. Changes in nitrate reductase activity and oxidative stress response in the moss Polytrichum commune subjected to chromium, copper and zinc phytotoxicity // Braz. J. Plant Physiol.-2005.-17, N 2.P.191-197.

21. Zaetz I.E., Voznyuk T.N., Kovalchuk M.V., Kramarev C.M., Kozyrovska N. O. Activity of bacteria consortium in soy agrocenoses on chernozems polluted with heavy metals in Prydniprovia region // Science and Innovation. -2007-3, № 6.-C. 26-36.

22. dos Santos Soares A. M., de Souza T. F., de Souza Domingues S. J., Jacinto T., Tavares Machado O. L. Methyl jasmonate promotes the transient reduction of the levels of 2-Cys peroxiredoxin in Ricinus communis plants // Plant Physiol. Biochem.-2004.-42.-P. 543-547.

23. Zaets I.E., Lukashov D. V., Mytrokhyn O. V., Mashkovska S. P., Kozyrovska N. O. Effect of bacteria on chemical element mobilization from anorthosite and optimal plant nutrition// Proceedings of the Uzhgorod Universiry. Series Biology. -2007.- Вип. 20.-С. 243-249. 